\begin{tabular}{|c|l|}
\hline Title & $\begin{array}{l}\text { Changes in microbial community composition in the leaf litter of successional communities after volcanic eruptions of } \\
\text { Mount U su, northern Japan }\end{array}$ \\
\hline Author(s) & Otaki, Michiru; Takeuchi, Fumiko; Tsuyuzaki, Shiro \\
\hline Citation & $\begin{array}{l}\text { Journal of mountain science, 13(9), 1652-1662 } \\
\text { https://doi.org/10.1007/311629-016-3835-4 }\end{array}$ \\
\hline Issue Date & 2016-09 \\
\hline Doc URL & http://hdl.handle.net/2115/67093 \\
\hline Rights & The final publication is available at link.springer.com \\
\hline Type & article (author version) \\
\hline File Information & JMS_AcceptedManuscript.pdf \\
\hline
\end{tabular}

Instructions for use 
Accepted: 6 May 2016

Citation: Otaki M, Takeuchi F, Tsuyuzaki S (2016) Changes in microbial community composition in the leaf litter of successional communities after volcanic eruptions of Mount

\title{
Changes in microbial community composition in the leaf litter of successional communities after volcanic eruptions of Mount Usu, northern Japan
}

\author{
Michiru OTAKI* http://orcid.org/oooo-ooo2-7423-9845; e-mail: moot@ees.hokudai.ac.jp \\ Fumiko TAKEUCHI http://orcid.org/oooo-0oo3-4822-5471; e-mail: \\ takeuchi235@gmail.com \\ Shiro TSUYUZAKI http://orcid.org/oooo-0003-3010-8699; e-mail: tsuyu@ees.hokudai.ac.jp
}

Graduate School of Environmental Science, Hokkaido University, N10W5, Sapporo 060-0810 Japan

\begin{abstract}
Changes in the fungal and bacterial biomass and community structure in litter after the volcanic eruptions of Mount Usu, northern Japan were investigated using a chronosequence approach, which is widely used for analyzing vegetation succession. The vegetation changed from bare ground (10 years after the eruptions) with little plant cover and poor soil to monotonic grassland dominated by Polygonum sachalinense with undeveloped soil (33 years) and then to deciduous broad-leaved forest dominated by Populus maximowiczii with diverse species composition and well-developed soil (100 years). At three chronosequential sites, we evaluated the compositions of phospholipid fatty acids (PLFAs), carbon (C) and nitrogen (N) contents and the isotope ratios of $\mathrm{C}\left(\delta^{13} \mathrm{C}\right)$ and $\mathrm{N}\left(\delta^{15} \mathrm{~N}\right)$ in the litter of two dominant species, Polygonum sachalinense and Populus maximowiczii. The $\mathrm{C} / \mathrm{N}$ ratio, $\delta^{13} \mathrm{C}$ and $\delta^{15} \mathrm{~N}$ in the litter of these two species were higher in the forest than that in the bare ground and grassland. The PLFAs gradually increased from the bare ground to the forest, showing that microbial biomass increased with the development of the soil and/or vegetation. The fungi-to-bacteria ratio of PLFA was constant at $5.3 \pm 1.4$ in all three sites, suggesting that fungi were predominant. A canonical correspondence analysis suggested that the PLFA composition was related to the successional ages and the developing soil properties $(P<0.05$, ANOSIM). The chronosequential analysis effectively detected the successional changes in both microbial and plant communities.
\end{abstract}

Keywords Volcanic succession; Fungi-to-bacteria ratio; Litter decomposition; Microbial community; Phospholipid fatty acids (PLFAs); Primary succession 


\section{Introduction}

Volcanic eruption is one of the triggers of primary succession, which begins with no plants or soils. Two major taxa, fungi and bacteria, contribute to litter decomposition, which promotes soil development. Bacterial composition is determined by vegetation development patterns during early primary succession in glacier forefields (Knelman et al. 2012). Mycorrhizal communities develop on old lava, whereas bacterial communities are stable independently of the lava age (Cutler et al. 2014). The contribution of bacteria to litter decomposition gradually increases with increasing time after the retreat of ice sheets (Pennanen et al. 2001). These previous findings have suggested that in addition to plant communities, the microbial communities of bacteria and fungi change with succession. Subsequently, the formation of soil organic matter is characterized by the patterns and processes of litter decomposition. On volcanoes after eruptions, ecological succession proceeds with soil development via litter decomposition. Therefore, investigating litter decomposition by bacteria and fungi along successional seres is helpful for understanding the mechanisms of ecological succession.

To investigate the contributions of bacteria and fungi to changes in litter decomposition along successional seres, the fungi-to-bacteria ratio (F/B ratio) was used. This ratio is affected by the chemical and physical properties of litter, such as the $\mathrm{pH}$, moisture, and the $\mathrm{C}$ and $\mathrm{N}$ contents (Rousk et al. 2010; Brockett et al. 2012). The compositions of fungi and bacteria in litter change with changes in the dominant plant species (Urbanová et al. 2015). Therefore, information regarding the temporal changes in microbial communities is required to understand the mechanisms of succession.

The analysis of stable isotopes is a useful tool for assessing the changes and translocations of chemical components in litter. Light isotopes tend to move faster than heavy isotopes (Glaser 2005, Ehleringer et al. 2000); therefore, the isotope ratio changes when chemical transportation occurs. Because litter decomposition by microbial activity is a chemical process, the ratios of stable $\mathrm{C}$ and $\mathrm{N}$ isotopes in litter can be used to detect the degrees of organic matter decomposition (Connin et al. 2001). Thus, we investigated the $\mathrm{C}$ and $\mathrm{N}$ isotopes in the litter.

Because various types of phospholipid fatty acids (PLFAs) are produced by bacteria and fungi, the PLFA compositions are used to estimate the biomass and composition of bacteria and fungi in litter (Helfrich et al. 2015). Chronosequencing is an advantageous method in which a short-term survey is used to characterize the pattern of long-term ecological changes, including plant succession. Therefore, we measured the chemical components related to the microbial biomass described above in three chronosequential vegetation stages (bare ground, grassland and forest) that developed during three different time periods after three different eruptions of a volcano. We addressed two objectives: (1) Could changes in microbial biomass be detected with the chronosequential approach? (2) Does the microbial decomposer community composition change during ecological succession?

\section{Materials and methods}

\subsection{Study sites}

The Mount Usu volcano is located in the southern part of Hokkaido Island, northern Japan $\left(42^{\circ} 32^{\prime} \mathrm{N}-33^{\prime} \mathrm{N}, 140^{\circ} 48^{\prime} \mathrm{E}-50^{\prime} \mathrm{E}, 150-727 \mathrm{~m}\right.$ elevation). In 2010 , the mean annual temperature was $9^{\circ} \mathrm{C}$ and the annual precipitation was $900 \mathrm{~mm}$ (Japan Meteorological Agency 2012). When litter sampling was conducted in 2010, the maximum monthly temperature was $24^{\circ} \mathrm{C}$ in August and the minimum was $-3.7^{\circ} \mathrm{C}$ in February. The peak of precipitation occurs in the typhoon season in autumn, and snow between November and April provides $18 \%$ of the annual precipitation. Volcanic ash and pumice are the major soil particles in this region. In the early stages of succession (from bare ground to grassland), the pH in the tephra and the soil on Mount Usu is acidic, at approximately 5-6 (Haruki and Tsuyuzaki 2001). The forest soil in the surveyed area is classified as acidic brown forest soil below $\mathrm{pH} 7$.

Three sites damaged by the 1910, 1977-1978 and 2000 eruptions were selected. These three eruptions occurred on the northern slope in $1910\left(42^{\circ} 34^{\prime} \mathrm{N}, 140^{\circ} 5 \mathrm{O}^{\prime} \mathrm{E}, 160 \mathrm{~m}\right.$ elevation), on the northeastern slope in $1977\left(42^{\circ} 33^{\prime} \mathrm{N}, 140^{\circ} 50^{\prime} \mathrm{E}\right.$, $470 \mathrm{~m}$ elevation), and on the northwestern slope in $2000\left(42^{\circ} 33^{\prime} \mathrm{N}, 140^{\circ} 49^{\prime} \mathrm{E}, 150 \mathrm{~m}\right.$ elevation). These three sites were surveyed in 2010, at 10, 33, and 100 years after the eruptions, respectively. The distances among the three sites were less than $2.5 \mathrm{~km}$. Because these three sites were closely established and received comparable damage 
from the respective eruptions, they were suitable for conducting a chronosequential analysis (Garcia-Romero et al. 2015).

\subsection{Chronosequence in vegetation and the environment}

Vegetation, soil and overstory openness were measured in each of the three sites. Plant cover for each species was assessed in three randomly established $10 \mathrm{~m} \times 10 \mathrm{~m}$ plots at each site in the summer of 2010. Fisheye photos were taken facing straight upward at $1.2 \mathrm{~m}$ and $0.5 \mathrm{~m}$ above the ground surface at 4-6 different locations in each plot. Overstory openness (\%) was measured in each photo with a Gap Light Analyzer (GLA) (Frazer et al. 1999) and was averaged in each plot. The soil profiles were observed in each site by excavation. Three soil layers, i.e., litter, humus and organic layers, were classified on the basis of their colors and textures, and the thickness of each layer was measured at three or six points with a ruler.

In total, the chronosequence showed that broad-leaved forest developed in the grasslands within 100 years. Two species were common throughout the succession: Polygonum sachalinense Fr. Schm. (Polygonaceae), which is a deciduous forb that develops in mono-specific grasslands and reaches a height of greater than $2 \mathrm{~m}$, and Populus maximowiczii A. Henry (Salicaceae), which is one of the pioneer trees after volcanic disturbances.

\subsection{Litter sampling}

The leaf litter of two dominant species, Polygonum sachalinense and Populus maximowiczii, produced in autumn 2009 was collected from the ground surface in late July 2010. Therefore, the collected litter had remained on the ground for ten months after the leaves had defoliated. When the sampling was conducted, minimal litter had been produced in the current year and could be visually excluded. Additionally, litter that was collected by shaking the plants was used as initial litter to evaluate the initial properties. In the surveyed period, snow coverage occurred from mid-December 2009 to early April 2010. Each litter sample was randomly collected from each $10 \mathrm{~m} \times 10 \mathrm{~m}$ plot. The amount of litter consisted of more than 30 leaves from three locations at each site. The samples were separately packed into paper bags and kept in a cooler box. Soon after the samples were brought to our laboratory, they were kept in a freezer at $-70^{\circ} \mathrm{C}$ in the dark until use. Each sample was separately ground for PLFA analysis.

\subsection{Chemical analysis}

Carbon $(\mathrm{C})$, nitrogen $(\mathrm{N})$, and their stable isotopes $\left({ }^{13 \mathrm{C}}\right.$ and $\left.{ }^{15} \mathrm{~N}\right)$ were measured to investigate the microbial biomass and litter decomposition (Boström et al. 2007; Osono et al. 2008), although the evaluations should be interpreted with caution in chronosequential studies. These four chemical elements were measured with a stable isotope ratio mass spectrometer (Finnigan MAT252, Thermo Fisher Scientific, Yokohama). The standards used were the Vienna Pee Dee Belemnite for carbon and atmospheric $\mathrm{N}$ for nitrogen. Before the measurements, the samples were freeze dried at $-50^{\circ} \mathrm{C}$ for $7-14$ days.

The ratios of $\mathrm{C}$ and $\mathrm{N}$ isotopes relative to the standard $\left(\delta^{15} \mathrm{~N}\right.$ and $\delta^{13} \mathrm{C}, \%$ ) in each sample were expressed by

$$
\delta^{13} \mathrm{C} \text { or } \delta^{15} \mathrm{~N}=\left[\left(R_{\text {sample }} / R_{\text {standard }}\right)-1\right] \times 10^{3},
$$

where $R_{\text {sample }}$ and $R_{\text {standard }}$ are the ${ }^{13} \mathrm{C} /{ }^{12} \mathrm{C}$ or ${ }^{15 \mathrm{~N} /{ }^{14} \mathrm{~N}}$ ratios in the sample and standard, respectively. $\delta^{13} \mathrm{C}$ is correlated with the lignin content in litter (DeBond et al. 2013). $\delta^{15} \mathrm{~N}$ indicates the nitrogen transfer in litter because microbial immobilization discriminates against ${ }^{15} \mathrm{~N}$ in favor of ${ }^{14} \mathrm{~N}$ (Michener and Lajtha 2007).

Total lipids were extracted from 1.o g freeze-dried litter soaked in a mixture of chloroform: methanol: deionized water (1:2:0.8, v/v/v) (White et al. 1979). After the two-phase partition, the lower layer containing lipids was extracted. The lipid extracts were digested with $500 \mathrm{ml}$ of $60 \%$ perchloric acid, $2300 \mu \mathrm{L}$ of $1.78 \mathrm{mM}$ ammonium molybdate solution and $100 \mu \mathrm{L}$ of Fiske-Subbarow reagent (Fiske and Subbarow 1925). After the extracts were heated to $90^{\circ} \mathrm{C}$, the total lipids were quantified on the basis of the absorbance of $\mathrm{PMo}_{12} \mathrm{O}_{40^{7-}}$ reacted with phosphate at $815 \mathrm{~nm}$ with a spectrophotometer (U-180o, Hitachi High-Tech, Tokyo).

The phospholipids were separated from the total lipids by using thin-layer chromatography with a silica gel under a developer (91:30:8 = acetone: benzene: water). The phospholipids were subjected to mild alkaline methanolysis, and the fatty acid methyl esters were detected with gas 
chromatography (G-300o Gas Chromatograph, Hitachi, Tokyo) with a frame ionization detector using a $30-\mathrm{m} 5 \%$ phenyl silicone capillary column ( $\mathrm{HP}-5)$ exposed to helium as a carrier gas. The temperatures of the injector and detector were adjusted to $270^{\circ} \mathrm{C}$. The temperature in the oven was kept at $160^{\circ} \mathrm{C}$ for $5 \mathrm{~min}$ and then rose at $1^{\circ} \mathrm{C} / \mathrm{min}$ up to $180^{\circ} \mathrm{C}$ and $10^{\circ} \mathrm{C} / \mathrm{min}$ up to $240^{\circ} \mathrm{C}$. PLFAs were identified and quantified in each sample by comparison with the internal standard, nonadecanoate fatty acid (19:0). Fatty acid methyl esters were identified using the standards and/or previous literature with a gas chromatograph-mass spectrometer (JMS-DX303HF, JEOL, Tokyo). The taxon-specific PLFAs were i14:0, i15:0, a15:0, 16:107t, 16:109, 16:107, 10Me-16:0, i17:0, a17:0, cy17:0, 17:0, 10Me-17:0, 10Me-18:0 and cy19:0 produced by bacteria and 18:2 produced by fungi (Šnajdr et al. 2011). Of these, 10Me-16:0, 10Me-17:0 and 10Me-18:0 are produced only by actinomycete bacteria and $16: 1 \omega 7$ is produced primarily by bacteria and to a lesser extent by arbuscular mycorrhizal fungi (Graham et. al 1995). Therefore, 16:1 17 was treated as the production of bacteria. Most of the 18:2 in litter was derived from fungi because plant-derived 18:2 vanishes soon after defoliation (Laczko et al. 2003). The other PLFAs were produced by plants, bacteria and/or fungi and were treated as PLFAs produced by miscellaneous organisms.

\subsection{Statistical analysis}

The ratio of carbon to nitrogen $(\mathrm{C} / \mathrm{N}$ ratio) in the litter was calculated to estimate the litter decomposition. The $\mathrm{C} / \mathrm{N}$ ratio decreases with increasing litter decomposition because microbial activities promote carbon mineralization and nitrogen accumulation (Šnajdr et al. 2011). The ratio of fungi to bacteria (F/B ratio) was calculated based on the PLFAs in each litter to estimate the dependence of litter decomposition on fungi and bacteria (Schneider et al. 2012). The $\mathrm{C} / \mathrm{N}$ ratio, $\mathrm{F} / \mathrm{B}$ ratio, phosphorus content in the lipids, and stable isotopes in the litter were compared between years after the eruptions and between litter species by using a generalized linear model (GLM) with an assumed Gaussian distribution. The interactions between litter species and years after eruptions were also examined. All significance levels were set at $P<0.05$.

A canonical component analysis (CCA) was used to investigate the characteristics of PLFAs in the litter. The species matrix consisted of PLFAs produced specifically by fungi and bacteria in each litter. The environmental matrix consisted of eleven factors: litter species, overstory openness, the thickness of each of the three soil layers (litter, humus and organic), $\mathrm{C}$ and $\mathrm{N}$ content, $\mathrm{C} / \mathrm{N}$ ratio, $\delta^{13} \mathrm{C}, \delta^{15} \mathrm{~N}$ content, and the years after the eruptions. The litter species were treated as categorical variables, and the others were treated as numerical variables. A permutation test for CCA was conducted by using the Bray-Curtis distance matrix to extract the significant axes. An analysis of similarities (ANOSIM) was performed on the years after the eruptions to examine the significant differences between the groups of sampling units (Anderson and Walsh 2013). All of the statistical analyses were performed with the software package $\mathrm{R}$ (ver. 3.1.3) (R Core Team 2015). CCA was conducted with the R library vegan (version 2.2.1) (Okasanen et al. 2015).

\section{Results}

\subsection{Chronosequential changes in vegetation}

The chronosequential vegetation changes, based on these surveys, were confirmed as follows.

The youngest site, in which 10 years had passed since the eruptions, was bare ground, had less than 10\% plant cover, and had no litter accumulation except in a few concave locations (Figure $1 \mathrm{~A}$ ). The overstory openness averaged $74 \% \pm 6 \%$ (Table 1), although the openness was underestimated because the slope of the crater rim was included in the estimation. The common species consisted of a forb, Polygonum sachalinense, and a tree, Populus maximowiczii. The tephra lacked humus and organic layers, i.e., the tephra was o cm deep.

The grasslands 33 years after the eruptions were dominated by Polygonum sachalinense with heights exceeding $2 \mathrm{~m}$ (Figure $1 \mathrm{~B}$ ). The overstory openness was $19 \% \pm 4 \%$, showing that the dense foliage of Polygonum sachalinense intercepted the solar radiation in summer. Therefore, the litter consisted primarily of Polygonum sachalinense. Populus maximowiczii was established sporadically and was less than $2 \mathrm{~m}$ in height. The soil showed an organic layer 
averaging $2 \pm 1 \mathrm{~cm}$ deep. The litter and humus layers were $3 \pm 1 \mathrm{~cm}$ and $2 \pm 2 \mathrm{~cm}$, respectively. An aggregated soil structure was not observed.

A forest dominated by Populus maximowiczii was established in the area damaged by the 1910 eruption (Figure 1C). The tree height was ca. $20 \mathrm{~m}$ with a closed overstory, and the openness averaged $9 \% \pm 1 \%$. The understory of less than $2 \mathrm{~m}$ in height was occupied by various herbs, with $70 \%$ total plant cover. The herb Polygonum sachalinense consisted of $10 \%$ of the cover, and the next most abundant cover type was forbs, such as Asperula odorata and Petasites japonicus in the understory. The litter species was diverse in the forest. The organic layer was less than $15 \mathrm{~cm}$ in depth and averaged $12 \pm 4 \mathrm{~cm}$. The litter layer was $2 \pm 1 \mathrm{~cm}$, and the humus layer was $0.6 \pm 0.3 \mathrm{~cm}$. An aggregated soil structure was detected in the organic layer.

\subsection{Changes in chemical components and isotopes in the litter}

$\delta^{13} \mathrm{C}$ was $-32 \%$ o $\pm 2 \%$ o (mean \pm standard deviation) in the initial litter of Polygonum sachalinense and $-31 \%$ o $\pm 0 \%$ in the initial litter of Populus maximowiczii, with no significant differences (Table 2). In the decomposed litter, $\delta^{13} \mathrm{C}$ was significantly higher in the bare ground $(-29 \%$ o $\pm 0 \%$ o $)$ and grassland $\left(-29 \%\right.$ o $\pm 1 \%$ ) than in the forest $(-31 \% \circ \pm 1 \%$ o $) . \delta^{15} \mathrm{~N}$ in the initial litter of Polygonum sachalinense was $0.3 \%$ o $\pm 4.0 \%$ and was significantly higher than in the initial litter of Populus maximowiczii, in which $\delta^{15 \mathrm{~N}}$ was $-4.8 \% \pm 1.4 \%$ o. $\delta^{15 \mathrm{~N}}$ in the decomposed litter did not differ among the sites or between the litter species. The interactions of $\delta^{15 \mathrm{~N}}$ among the litter species and the sites were significant in the forest, showing that with the progression of succession, $\delta^{15} \mathrm{~N}$ decreased to a greater extent in the Polygonum sachalinense litter than in the Populus maximowiczii litter.

The $\mathrm{P}$ of phospholipids averaged $430 \pm 10 \mu \mathrm{g} / \mathrm{g}$ in the initial litter of Polygonum sachalinense and $348 \pm 75 \mu \mathrm{g} / \mathrm{g}$ in the initial litter of Populus maximowiczii. The P content in decomposed litter was not different between the species (GLM, $P>0.05$ ). The P in the phospholipids was $63 \mu \mathrm{g} / \mathrm{g}$ litter in the bare ground, $96 \mu \mathrm{g} / \mathrm{g}$ in the grassland, and $130 \mu \mathrm{g} / \mathrm{g}$ in the forest (Table 2). The phospholipids in litter increased significantly during succession without interactions between litter species and sites.

The $\mathrm{C}$ content in the initial litter was $47 \% \pm 4 \%$ in Populus maximowiczii and $45 \% \pm 0 \%$ in Polygonum sachalinense and was not different between the litter species. The $\mathrm{N}$ content in the initial litter averaged $3 \% \pm 1 \%$ in Populus maximowiczii and $3 \% \pm 0 \%$ in Polygonum sachalinense, and hence was not different between species. The $\mathrm{N}$ contents in the decomposed litter were significantly lower in the bare ground and grassland than in the forest. The $\mathrm{C} / \mathrm{N}$ ratios were significantly lower in the forest than in the bare ground and grassland and were not significantly different between the litter species.

\subsection{Microbial biomass}

In total, 19 PLFAs were detected and identified in all the litter samples. Of these, 18:2 was from fungi, and i15:0, a15:0, 16:1 07 , a17:0, 17:0 and 10Me-18:0 were from bacteria in both the initial and decomposed litter. The initial litter contained $908 \pm 303 \mu \mathrm{g} / \mathrm{g}$ PLFAs. Bacterial and fungal PLFAs averaged $10 \pm 2 \mu \mathrm{g} / \mathrm{g}$ and $216 \pm 64 \mu \mathrm{g} / \mathrm{g}$, respectively. The average concentration of 16:1 107 ranged from $10 \pm 3 \mu \mathrm{g} / \mathrm{g}$ in the bare ground to $44 \pm 12 \mu \mathrm{g} / \mathrm{g}$ in the forest. Because 16:1 107 was produced by bacteria, the contribution of bacteria to the microbial biomass was reduced (Figure 2). The total PLFA content increased significantly with sites independent of the litter species. The PLFAs in the bare ground were $1 / 2$ and $1 / 4$ of those in the grasslands and forests, respectively. These results indicated that the biomass of microbial organisms increased across the chronosequential succession. The PLFA marker of fungi, 18:2, increased five-fold from $112 \mu \mathrm{g} / \mathrm{g}$ at 10 years after the eruptions to $497 \mu \mathrm{g} / \mathrm{g}$ at 100 years after the eruptions, and the bacterial PLFA contents increased four-fold from $24 \mu \mathrm{g} / \mathrm{g}$ in the bare ground to $91 \mu \mathrm{g} / \mathrm{g}$ in the forest. The miscellaneous PLFAs were 3.7 times higher in the forest than in the bare ground ( $967 \mu \mathrm{g} / \mathrm{g}$ vs. $263 \mu \mathrm{g} / \mathrm{g}$, respectively). Because the plant leaves did not produce any PLFAs after defoliation, the detected PLFAs were produced by microbial activities. The fungi-to-bacteria ratios averaged $5.3 \pm 1.4$ and did not differ significantly among the three sites and between the two litter species.

\subsection{Canonical correspondence analysis of PLFAs}


The CCA performed by using the composition of PLFAs showed that the variations were $46 \%$ for axis I and $37 \%$ for axis II (Figure 3). The cumulative variations of the two axes reached $83 \%$. The permutation test of the CCA showed that the first two axes were significant. ANOSIM indicated that the years after the eruptions, canopy openness and soil layers were significant variables in each of the separate groups. The scores of the bare ground were much different from the scores of the grassland and the forest over time after the eruptions, and the scores of the grassland and the forest roughly overlapped. These trends indicated that the compositions of PLFAs in the litter differed between the nonvegetated (open-canopy) and vegetated (closed-canopy) habitats. In addition, the scores of the forest exhibited a wide range, which indicated that the compositions of PLFAs in the litter became diverse in the forest.

The overstory openness was negatively correlated with the number of years after the eruptions (Figure 3). The thicknesses of the organic and litter layers in the soils were positively correlated with the number of years after the eruptions, showing that the soil developed chronologically. However, the thickness of the humus layer was not greatly related to the successional ages of the eruptions. The angles of the litter species, Populus maximowiczii and Polygonum sachalinense, were approximately orthogonal to the ages, and their positions close to the origin indicated that the litter species was not strongly related to the composition of PLFAs.

The PLFA produced by fungi, i.e., 18:2, was positioned near the origin of the CCA plot (Figure 3), indicating that most of the litter contained 18:2 produced by fungi. Of the PLFAs produced by bacteria, the scores of 10Me-18:0 represented the PLFAs detected from the grassland and the scores of a17:0 represented the PLFAs compositions in the bare ground. These results indicated that bacterial flora changed along the chronosequence. The other bacterial PLFAs compositions were common in the litter, showing that certain bacteria were present in these three habitats.

\section{Discussion}

\subsection{Succession of microbial communities investigated through PLFAs}

The chronosequential approach, which has been widely used in vegetation science, demonstrated that the PLFA contents produced by fungi and bacteria increased with increasing successional ages after the eruptions of Mount Usu. PLFAs that were produced by both bacteria and fungi were classified into miscellaneous PLFAs; thus, their origins were not determined. However, the miscellaneous PLFAs produced by microbial activities also increased over time. The phosphorous in lipids gradually increased with succession on Mount Usu. This increase was most probably derived primarily from an increase in the PLFA content. Phosphorus fluctuations in litter have been shown to be synchronized with fluctuations in the soil with volcanic succession on the Hawaiian Islands, i.e., the phosphorus content increases from the early to middle stages and decreases from middle to late stages (Crews et al. 1995). The phosphorus in the lipids of the litter still increased with succession on Mount Usu. Because the Populus maximowiczii forest was in the early and middle successional stages, the phosphorus in the litter increased and the litter decomposition accelerated toward the climax vegetation (Crews et al. 1995).

The composition of PLFAs and CCA based on PLFAs showed that the biomass of fungi and bacteria was higher in the grassland and forest than the bare ground. The PLFA contents, C/N ratio, $\delta^{13} \mathrm{C}$ and $\delta^{15} \mathrm{~N}$ in the forests were significantly different from those in the bare ground and grassland, i.e., the forest showed the highest PLFA content and lowest C/N ratio, $\delta^{13} \mathrm{C}$ and $\delta^{15} \mathrm{~N}$. Therefore, not only the soil properties but also the aboveground vegetation structure probably influences the microbial biomass and composition.

\subsection{The effects of $C$ and $N$ contents of litter microorganisms}

The $\delta^{15} \mathrm{~N}$ in the litter that had remained for 10 months after the defoliation did not differ between the two examined species, Polygonum sachalinense and Populus maximowiczii, whereas the $\delta^{15} \mathrm{~N}$ in the initial litter was higher in Polygonum sachalinense than in Populus maximowiczii. The leakage of dissolved organic matter from litter occurs rapidly after 
defoliation (Bourbonniere and Creed 2006), and soluble organic matter content differs among plant species (Taylor and Barlocher 1996). The leakage of $\mathrm{N}$ may have been faster from the Polygonum sachalinense litter than from the Populus maximowiczii litter. The results of GLM for $\delta^{15} \mathrm{~N}$ and $\delta^{13} \mathrm{C}$ showed that the interactions between the litter species and the years were statistically significant. These results indicated that decreases in $\delta^{15} \mathrm{~N}$ and $\delta^{13} \mathrm{C}$ became more pronounced with succession.

However, the CCA and GLM analyses showed that the litter species had a small effect on the compositions of the taxon-specific composition of PLFAs. The chemical properties in the initial litter were likely to be different between the two litter species, although the contents of $\mathrm{C}$ and $\mathrm{N}$ in the initial litter were not. These results suggested that the translocation of nutrients from leaves formed litter of similar quality. In general, tree litter decomposes more slowly than herb litter due to its low nitrogen content, which in particular is derived from slowly dissolving lignin (Enriquez et al. 1993). $\mathrm{C}_{3}$ and $\mathrm{C}_{4}$ plants generally show $\delta^{13} \mathrm{C}$ values $-36 \%$ o $\pm 3 \%$ and $-21 \%$ o $\pm 2 \%$, respectively (Chikaraishi and Nagaoka 2003), thus indicating that Populus maximowiczii and Polygonum sachalinense are $\mathrm{C}_{3}$ plants. $\delta^{13} \mathrm{C}$, an indicator of lignin content (Wedin et al. 1995), did not differ between the two litter species. Therefore, both the Populus maximowiczii and Polygonum sachalinense litter decomposed rapidly. Litter decomposability has been consistently related to the ecological strategy of plant species (Cornwell et al. 2008). Because Populus maximowiczii and Polygonum sachalinense are often established sympatrically soon after volcanic eruptions (Tsuyuzaki 1987), their ecological strategies are likely convergent; thus, the effects of litter species on the litter decomposition were not clearly detected in the early and middle stages of succession. Because the $\mathrm{C}$ content in the litter does not change greatly among most vascular plant species, the $\mathrm{N}$ content and its related variables, such as the $\mathrm{C} / \mathrm{N}$ ratio, in plant substrates should be included in descriptions of litter decomposition patterns.

\subsection{Successional changes in fungi and bacteria}

The PLFAs showed that the biomass of fungi and bacteria increased with succession on Mount Usu. In addition, the F/B ratio did not differ among the three sites and was constant along the successional seres. The biomass of fungi and bacteria is positively correlated to litter decomposition rate (Neely et al. 1991). These results suggested that the litter decomposition occurred more rapidly with succession and with constant contribution rates, shown by $\mathrm{F} / \mathrm{B}$ ratios. The fungi-to-bacteria ratio is influenced by soil pH (Båăth and Anderson 2003). The soils and volcanic deposits on Mount Usu are acidic, although the soil chemical properties in each of the three sites were not measured in this study. The phosphorus and nitrogen contents in the soil were likely to increase with time and in synchrony with the changes in PLFAs. However, these changes did not affect the F/B ratio. Further studies are required to detect why fungal PLFAs were dominant throughout succession.

In nutrient-poor soil, mycorrhizal fungi contribute more to litter decomposition than bacteria in soil-pore water (Unestam and Sun 1991) because fungi transport nutrients through elongated hyphae (Brunner 2001). Fungi are more advantageous to litter decomposition than bacteria when the soil is dry, acidic and/or depleted (Blagodatskaya and Anderson 1998). Fungal communities play a dominant role in early stages of litter breakdowns in black alder forests, whereas bacteria complete the mineralization of C (Dilly et al. 2001). Laboratory experiments have shown that the fungi-to-bacteria ratio increases with decreasing $\mathrm{pH}$ over a range of 9 to 3 (Båăth and Anderson 2003); in contrast, the fungi-to-bacteria ratio increases when the soil in cool, temperate forests undergoes a dry/wet cycle (Scheu and Parkinson 1994). The fungi-to-bacteria ratio has been shown to increase gradually in primary succession on a glacier forefront during primary succession from bare ground to needle-leaved boreal forests in Scandinavia (Pennanen et al. 2001). Microbial activities are regulated by the habitat characteristics determined by the litter quality (Dilly and Munch 2004). The differences in the activities of fungi and bacteria are likely to be derived from litter quality, i.e., forbs or trees (Cornwell et al.2008). The volcanic deposits on Mount Usu are acidic and often become dry, even in the forests. Therefore, the characteristics of volcanic deposits should benefit the presence of fungi.

In conclusion, the biomass of fungi and bacteria in litter increased with the successional stages with constant F/B ratios throughout the succession. This pattern probably occurred because the characteristics of volcanic ejecta, i.e., the porosity and permeability of volcanic deposits, persist for several decades or up to a century. 


\section{Acknowledgements}

We are grateful to Profs. T. Yoshimura, H. Nishimura and S. Takenaka, Tokai University, for the use of laboratory space and instruments. We would like to thank Prof. T. Sakaki, Junior Assoc. Prof. A. Satoh, Tokai University, for advice. We would also like to thank the five anonymous reviewers for improving the manuscript.

\section{References}

Anderson M, Walsh D (2013) PERMANOVA, ANOSIM, and the Mantel test in the face of heterogeneous dispersions: What null hypothesis are you testing? Ecological Monographs 83: 557-574.

Bååth E, Anderson TH (2003) Comparison of soil fungal/bacterial ratios in a pH gradient using physiological and PLFA-based techniques. Soil Biology and Biochemistry 35:955-963. DOI: 10.1016/So038-0717(03)00154-8

Blagodatskaya EV, Anderson T (1998) Interactive effects of $\mathrm{pH}$ and substrate quality on the fungal-to-bacterial ratio and qCO2 of microbial communities in forest soils. Soil Biology \& Biochemistry 30 :1269-1274. DOI: 10.1016/s0038-0717(98)00050-9

Boström B, Comstedt D, Ekblad A (2007) Isotope fractionation and $13 \mathrm{C}$ enrichment in soil profiles during the decomposition of soil organic matter. Oecologia 153: 89-98. DOI: 10.1007/s00442-007-0700-8

Bourbonniere RA, Creed IF (2006) Biodegradability of dissolved organic matter extracted from a chronosequence of forest-floor materials. Journal of Plant Nutrition and Soil Science 169: 101-107. DOI: 10.1002/jpln.200521721

Brockett BFT, Prescott CE, Grayston SJ (2012) Soil moisture is the major factor influencing microbial community structure and enzyme activities across seven biogeoclimatic zones in western Canada. Soil Biology and Biochemistry 44: 9-20. DOI: 10.1016/j.soilbio.2011.09.003

Brunner I (2001) Ectomycorrhizas: their role in forest ecosystems under the impact of acidifying pollutants. Perspectives in Plant Ecology Evolution and Systematics 4: 13-27. DOI: 10.1078/1433-8319-00012

Chikaraishi Y, Naraoka H (2003) Compound-specific $\delta \mathrm{D}-\delta 13 \mathrm{C}$ analyses of n-alkanes extracted from terrestrial and aquatic plants. Phytochemistry 63: 361-371. DOI: 10.1016/Soo31-9422(02)00749-5

Connin SL, Feng X, Virginia RA (2001) Isotopic discrimination during long-term decomposition in an arid land ecosystem. Soil Biology and Biochemistry 33: 41-51. DOI: 10.1016/So038-0717(00)00113-9

Cornwell WK, Cornelissen JHC, Amatangelo K, et al (2008) Plant species traits are the predominant control on litter decomposition rates within biomes worldwide. Ecology Letters 11: 1065-1071. DOI: 10.1111/j.1461-0248.2008.01219.x

Crews TE, Kitayama K, Fownes JH, et al (1995) Changes in Soil Phosphorus Fractions and Ecosystem Dynamics across a Long Chronosequence in Hawaii. Ecology 76: 1407-1424.

Cutler NA, Chaput DL, van der Gast CJ (2014) Long-term changes in soil microbial communities during primary succession. Soil Biology and Biochemistry 69: 359-370. DOI: 10.1016/j.soilbio.2013.11.022

DeBond N, Fogel ML, Morrill PL, et al (2013) Variable delta D values among major biochemicals in plants: Implications for environmental studies. Geochimica Et Cosmochimica Acta 111: 117-127. DOI: 10.1016/j.gca.2012.10.043

Dilly O, Bartsch S, Rosenbrock P (2001) Shifts in physiological capabilities of the microbiota during the decomposition of leaf litter in a black alder (Alnus glutinosa (Gaertn.) L.) forest. Soil Biology and Biochemistry 33: 921-930.

Dilly O, Munch JC (2004) Litter decomposition and microbial characteristics in agricultural soil in Northern, Central, and Southern Germany. Soil Science and Plant Nutrition 50: 843-853. DOI: 10.1080/00380768.2004.10408545

Ehleringer JR (2000) Carbon isotope ratios in belowground carbon cycle processes. Ecological Applications 10: 412-422.

Enríquez S, Duarte CM, Sand-Jensen K (1993) Patterns in decomposition rates among photosynthetic organisms: the importance of detritus C:N:P content. Oecologia 94: 457-471. 
DOI: $10.1007 /$ BFo0566960

Fiske CH, Subbarow Y (1925) The colorimetric determination of phosphorus. Journal of Biological Chemistry 66: 375-400.

Frazer GW, Canham CD, Lertzman KP (1999) Gap Light Analyzer (GLA), Version 2.o: Imaging software to extract canopy structure and gap light transmission indices from true-colour fisheye photographs, Users Manual And Program Documentation. Copyright (C) 1999: Simon Fraser University, Burnaby, British Columbia, and the Institute of Ecosystem Studies, Millbrook, New York. Available online at: http://citeseerx.ist.psu.edu/viewdoc/download?doi=10.1.1.458.1223\&rep=rep1\&type=pdf (Accessed 19 April 2016)

Garcia-Romero A, Alanis-Anaya R, Munoz-Jimenez J (2015) Environmental Factors that Affect Primary Plant Succession Trajectories on Lahars (Popocatép petl Volcano, M Mexico). Journal of Mountain Science 12: 1254-1266.

Glaser B (2005) Compound-specific stable-isotope $\left(\delta^{13} \mathrm{C}\right)$ analysis in soil science. Journal of Plant Nutrition and Soil Science 168: 633-648. DOI: 10.1002/jpln.200521794

Graham JH, Hodge NC, Morton JB, et al (1995) Fatty Acid Methyl Ester Profiles for Characterization of Glomalean Fungi and Their Endomycorrhizaet. Applied and Environmental Microbiology 61: 58-64.

Haruki M, Tsuyuzaki S (2001) Woody plant establishment during the early stages of volcanic succession on Mount Usu, northern Japan. Ecological Research 16: 451-457. DOI: 10.1046/j.1440-1703.2001.00407.x

Helfrich M, Ludwig B, Thoms C, et al (2015) The role of soil fungi and bacteria in plant litter decomposition and macroaggregate formation determined using phospholipid fatty acids. Applied Soil Ecology 96: 261-264. DOI: 10.1016/j.apsoil.2015.08.023

Japan Meteorological Agency (2012) Japan Meteorological Agency Homepage Available online at: http://www.data.jma.go.jp/obd/stats/etrn/view/monthly_a1.php?prec_no=21\&block_no= 0128\&year=2010\&month=\&day=\&view=.2013: (Accessed 19 April 2016)

Johnson EA, Miyanishi K (2008) Testing the assumptions of chronosequences in succession. Ecology Letters 11: 419-431. DOI: 10.1111/j.1461-0248.2008.01173.x

Knelman JE, Legg TM, O’Neill SP, et al (2012) Bacterial community structure and function change in association with colonizer plants during early primary succession in a glacier forefield. Soil Biology and Biochemistry 46: 172-180. DOI: 10.1016/j.soilbio.2011.12.001

Laczko E, Boller T, Wiemken V (2004) Lipids in roots of Pinus sylvestris seedlings and in mycelia of Pisolithus tinctorius during ectomycorrhiza formation: changes in fatty acid and sterol composition. Plant Cell and Environment 27: 27-40. DOI: 10.1046/j.0016-8025.2003.01122.x

Michener R, Lajtha K (2007) Stable isotope studies in marine chemoautotrophically based ecosystems: An update. Blackwell publishing, Oxford, UK.

Neely CL, Beare MH, Hargrove WL, et al. (1991) Relationships between fungal and bacterial substrate-induced respiration, biomass and plant residue decomposition. Soil Biology and Biochemistry 23: 947-954. DOI: 10.1016/0038-0717(91)90175-J

Oksanen J, Blanchet FG, Kindt R, et al. (2015). vegan: Community Ecology Package. R package version 2.2-1. Available online at: http://CRAN.R-project.org/package=vegan (Accessed 19 April 2016)

Osono T, Takeda H, Azuma JI (2008) Carbon isotope dynamics during leaf litter decomposition with reference to lignin fractions. Ecological Research 23: 51-55. DOI: 10.1007/s11284-007-0336-5

Pennanen T, Strommer R, Markkola A, et al. (2001) Microbial and plant community structure across a primary succession gradient. Scandinavian Journal of Forest Research 16: 37-43.

R Core Team (2015).R: A language and environment for statistical computing. R Foundation for Statistical Computing, Vienna, Austria. Available online at: http://www.R-project.org/ (Accessed 19 April 2016)

Rousk J, Bååth E, Brookes PC, et al (2010) Soil bacterial and fungal communities across a pH gradient in an arable soil. The ISME journal 4: 1340-1351. DOI: $10.1038 /$ ismej.2010.58

Scheu S, Parkinson D (1994) Changes in bacterial and fungal biomass C, bacterial and fungal biovolume and ergosterol content after drying, remoistening and incubation of different layers of cool temperate forest soils. Soil Biology and Biochemistry 26: 1515-1525. DOI: 10.1016/0038-0717(94)90093-0 
Schneider T, Keiblinger KM, Schmid E, et al. (2012) Who is who in litter decomposition? Metaproteomics reveals major microbial players and their biogeochemical functions. ISME Journal 6: 1749-1762. DOI: 10.1038/ismej.2012.11

Šnajdr J, Cajthaml T, Valaskova V, et al. (2011) Transformation of Quercus petraea litter: successive changes in litter chemistry are reflected in differential enzyme activity and changes in the microbial community composition. FEMS Microbiology Ecology 75: 291-303. DOI: $10.1111 / \mathrm{j} .1574-6941.2010 .00999 . \mathrm{x}$

Taylor BR, Barlocher F (1996) Variable effects of air-drying on leaching losses from tree leaf litter. Hydrobiologia 325: 173-182. DOI: 10.1007/BFoo014982

Tsuyuzaki S (1987) Origin of plants recovering on the volcano Usu, northern Japan, since the eruptions of 1977 and 1978. Vegetatio 73: 53-58. DOI: 10.1007/BFooo31851

Unestam T, Sun YP (1995) Extramatrical structures of hydrophobic and hydrophilic ectomycorrhizal fungi. Mycorrhiza 5: 301-311. DOI: 10.1007/bfoo207402

Urbanová M, Šnajdr J, Baldrian P (2015) Composition of fungal and bacterial communities in forest litter and soil is largely determined by dominant trees. Soil Biology and Biochemistry 84: 53-64. DOI: 10.1016/j.soilbio.2015.02.011

Wedin DA, Tieszen LL, Dewey B, et al. (1995) Carbon isotope dynamics during grass decomposition and soil organic matter formation. Ecology 76: 1383-1392. DOI: $10.2307 / 1938142$

White DC, Davis WM, Nickels JS, et al. (1979) Determination of the sedimentary microbial biomass by extractible lipid phosphate. Oecologia 40: 51-62. DOI: 10.1007/BFo0388810
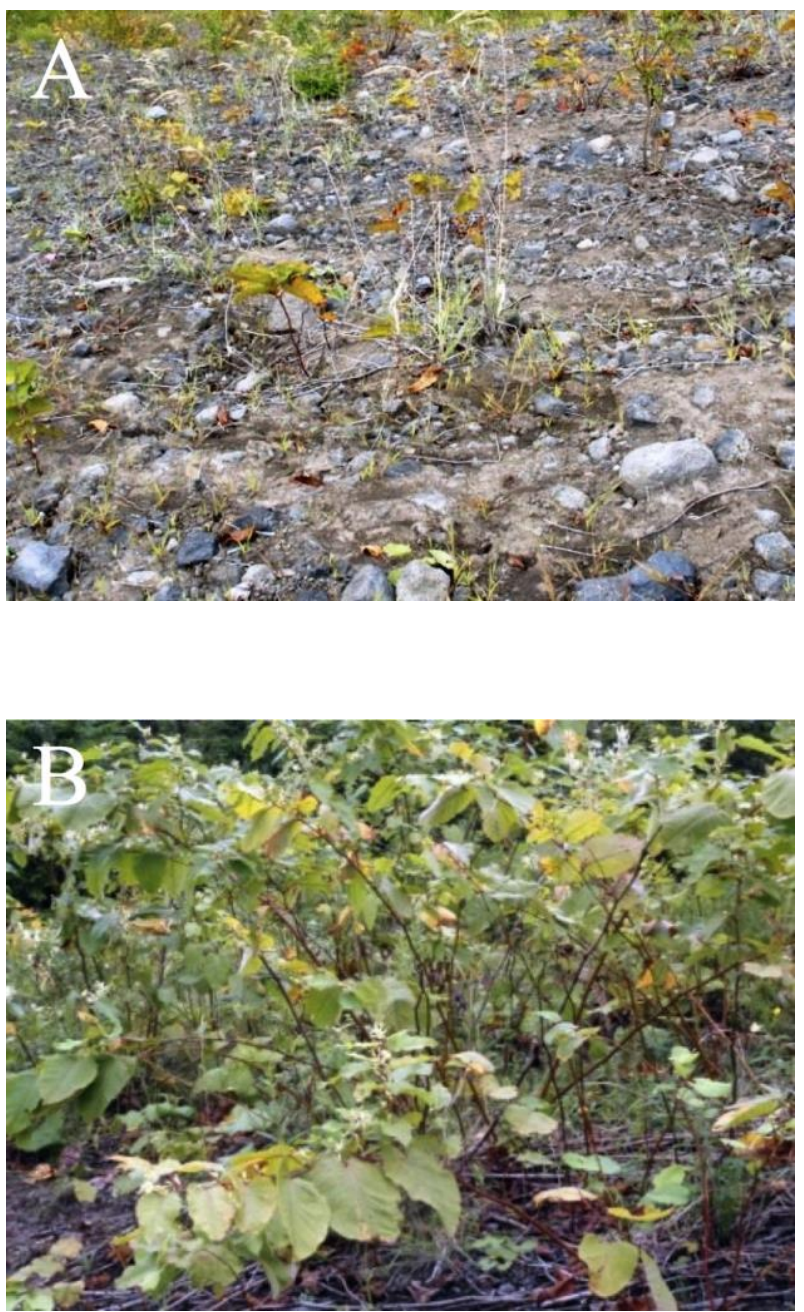


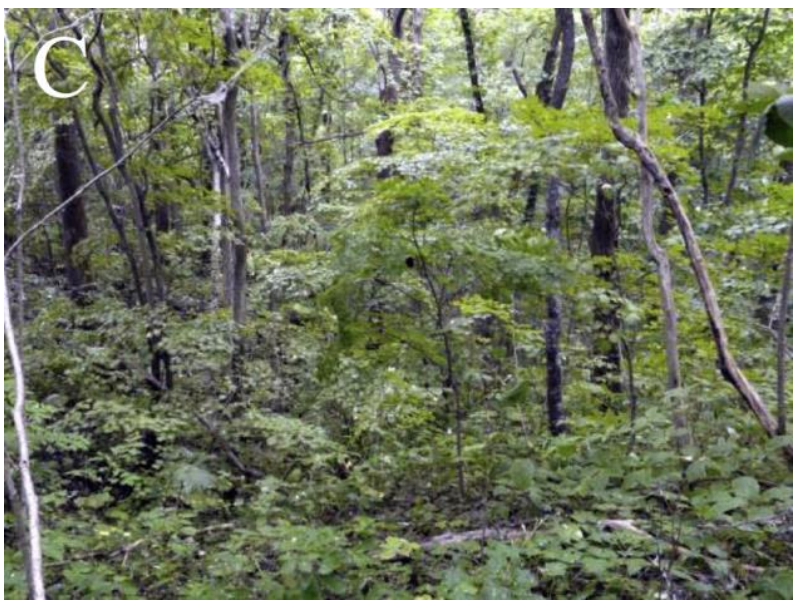

Figure 1 The landscapes of the three study sites on Mount Usu. (A) Bare ground formed by the 2000 eruption (photo taken on September 8, 2009). (B) Grassland dominated by Polygonum sachalinense in an area damaged by the 1977-78 eruption (August 25, 2010). (C) A forest dominated by Populus maximowiczii, which developed after the 1910 eruptions (August 10, 2011).

11

12

13

14

15

16

17

18

19

20

21

22

23

24

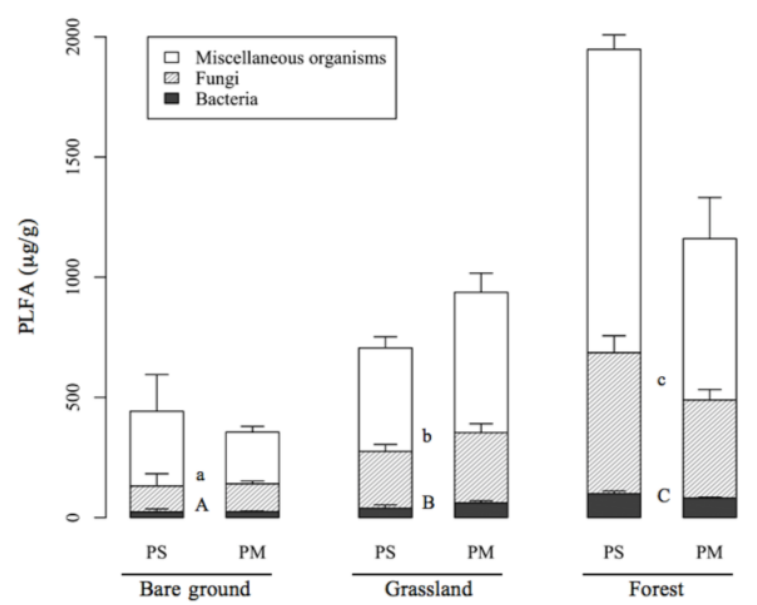

Figure 2 PLFAs produced by bacteria that were evaluated by the sum of i15:0, a15:0, 16:1 $\rceil_{7}$, a17:0, 17:0 and 10Me-18:0 (closed columns); fungi evaluated by the sum of 18:2 (hatched columns); and miscellaneous organisms evaluated by the sum of 14:0, 15:0, i16:0, 16:0, br17:0,

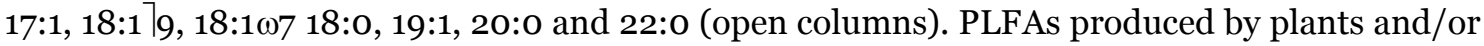
microbes (bacteria and/or fungi) were classified into miscellaneous organisms. PS = Polygonum sachalinense litter, and PM = Populus maximowiczii litter. Different lowercase and uppercase letters indicate significant between-year differences in fungal and bacterial PLFAs, respectively (GLM, $P<0.05)$. The PLFAs were not significantly different between litter species $(P>0.05)$. 


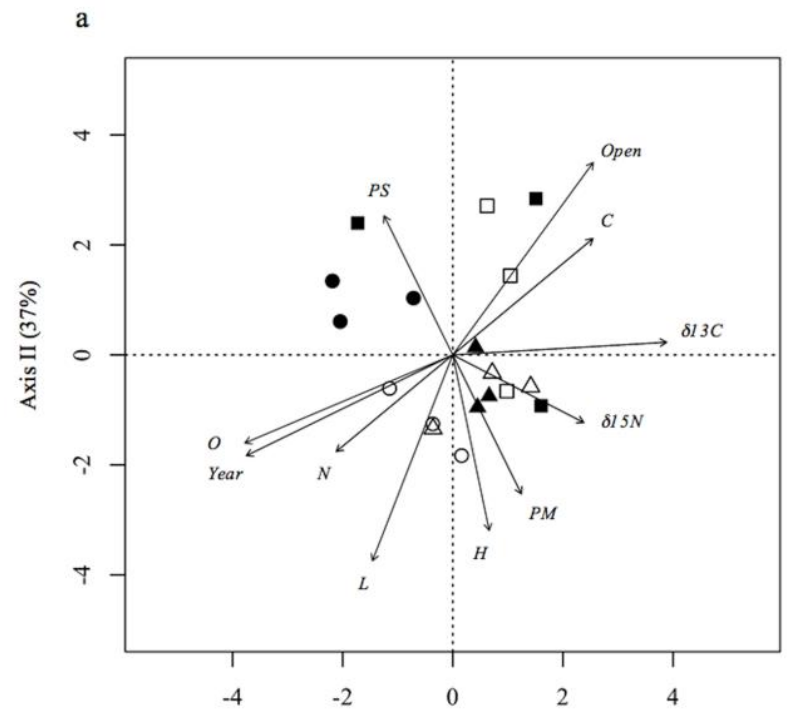

1

Axis I (46\%)

b

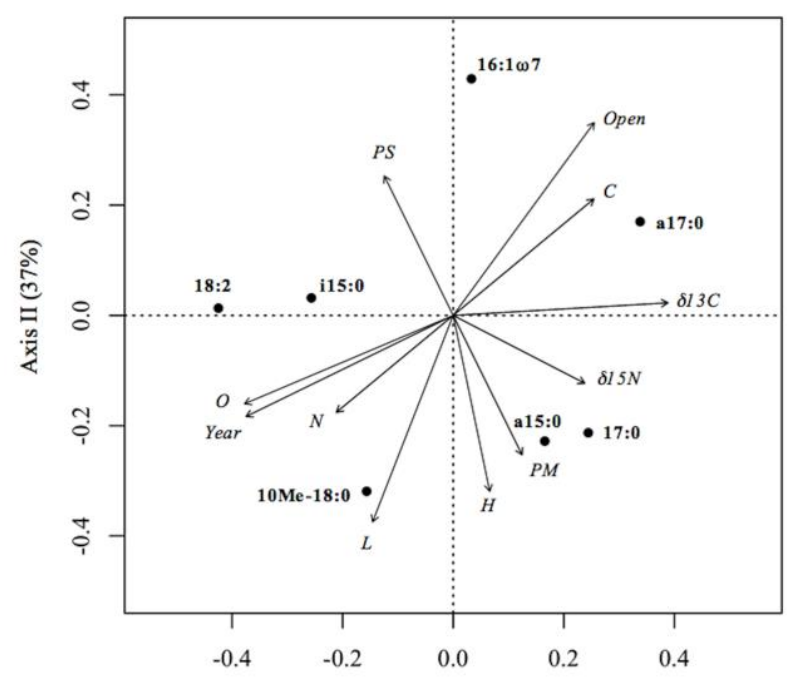

Axis I (46\%)

Figure 3 CCA conducted by using PLFAs produced by bacteria and fungi in litter. The litter was collected from the three sites with different ages. The contribution rates on the first two axes are shown in parentheses to the right of the axis label. (a) The scores of litter of the two examined species collected from the three sites. The open and closed symbols show the litter of Populus maximowiczii and Polygonum sachalinense, respectively. The years after the eruptions are indicated as follows: Circles = forest; triangles = grassland; and squares = bare ground. Environmental factors: soil organic layer $=O$; humus layer $=H$; litter layer $=L$; canopy openness $=$ Open; years after the eruptions $=$ Year $; \mathrm{C}$ content $(\%)=C ; \mathrm{N}$ content $(\%)=\mathrm{N} ; \mathrm{C} / \mathrm{N}$ ratio $=\mathrm{C} / \mathrm{N} ; \delta^{13} \mathrm{C}$ content $=\delta^{13} \mathrm{C} ; \delta^{15} \mathrm{~N}$ content $=\delta^{15} \mathrm{~N} ;$ Polygonum sachalinense litter $=P S$; and Populus maximowiczii litter $=P M$. (b) The PLFA scores of i15:0, a15:0, 16:107, a17:0, 17:0 and 10Me-18:0 are produced by bacteria, and 18:2 is produced by fungi. Note that the scales of figures (a) and (b) are different.

Table 1 The ages, soil layer depths, and overstory openness of the studied sites.

\begin{tabular}{|l|l|l|l|l|l|} 
& Years from eruption & L layer & H layer & O layer & Overstory openness \\
\hline bareground & 10 & $0.0 \pm 0.0$ & $0.0 \pm 0.0$ & $0.0 \pm 0.0$ & $74.3 \pm 5.5$ \\
\hline grassland & 33 & $2.8 \pm 1.3$ & $1.7 \pm 1.5$ & $2.2 \pm 0.8$ & $19.4 \pm 4.0$ \\
forest & 100 & $2.4 \pm 0.5$ & $0.6 \pm 0.3$ & $11.6 \pm 3.9$ & $9.2 \pm 0.5$ \\
\hline
\end{tabular}


Table 2 The $\mathrm{C}, \mathrm{N}, \mathrm{C} / \mathrm{N}$ ratio, $\delta^{13} \mathrm{C}, \delta^{15} \mathrm{~N}$, and phosphorus (P) in the litter of Populus maximowiczii and Polygonum sachalinense, which were collected from three different sites (bare ground, grassland and forest). Each numeral shows the mean and the standard deviation. The total $\mathrm{P}$ in the phospholipids is shown. Different letters indicate significant differences between litter species or between years (GLM, $P<$ 0.05).

\begin{tabular}{|c|c|c|c|c|c|c|}
\hline & $\mathrm{C}(\%)$ & $\mathrm{N}(\%)$ & $\mathrm{C} / \mathrm{N}$ & $\delta^{13} \mathrm{C}(\%)$ & $\delta^{15 N}(\%)$ & $\mathrm{P}(\mu \mathrm{g} / \mathrm{g})$ \\
\hline \multicolumn{7}{|c|}{ Populus maximowiczii } \\
\hline initial litter & $46.5 \pm 4.21$ & $2.48 \pm 0.77$ & $19.94 \pm 7.86$ & $-31.0 \pm 0.28$ & $-4.83 \pm 1.37$ & $347.8 \pm 75.3$ \\
\hline bareground & $44.2 \pm 5.09 \mathrm{a}$ & $1.16 \pm 0.20 \mathrm{a}$ & $39.6 \pm 12.1 \mathrm{a}$ & $-28.6 \pm 0.25 \mathrm{a}$ & $0.77 \pm 0.13 \mathrm{a}$ & $75.3 \pm 13.8 \mathrm{a}$ \\
\hline grassland & $41.0 \pm 1.13 \mathrm{a}$ & $1.44 \pm 0.19 \mathrm{a}$ & $28.9 \pm 3.83 \mathrm{a}$ & $-28.9 \pm 0.73 a$ & $1.44 \pm 0.19 \mathrm{a}$ & $113.0 \pm 24.6 b$ \\
\hline forest & $40.0 \pm 1.83 a$ & $1.80 \pm 0.20 \mathrm{~b}$ & $22.4 \pm 1.62 \mathrm{~b}$ & $-30.3 \pm 0.53 b$ & $1.68 \pm 0.04 \mathrm{a}$ & $118.4 \pm 1.24 \mathrm{c}$ \\
\hline \multicolumn{7}{|c|}{ Polygonum sachalinense } \\
\hline initial litter & $45.1 \pm 0.28$ & $2.93 \pm 0.34$ & $15.49 \pm 1.69$ & $-31.8 \pm 2.33$ & $0.31 \pm 4.04$ & $429.8 \pm 10.4$ \\
\hline bareground & $47.5 \pm 16.3 \mathrm{a}$ & $1.20 \pm 0.64 \mathrm{a}$ & $46.1 \pm 18.1 \mathrm{a}$ & $-28.8 \pm 0.28 a$ & $0.11 \pm 1.62 \mathrm{a}$ & $51.6 \pm 20.4 \mathrm{a}$ \\
\hline grassland & $43.5 \pm 0.54 \mathrm{a}$ & $1.08 \pm 0.26 \mathrm{a}$ & $42.2 \pm 11.5 \mathrm{a}$ & $-28.2 \pm 0.93 a$ & $1.08 \pm 0.26 \mathrm{a}$ & $78.9 \pm 15.0 \mathrm{~b}$ \\
\hline forest & $43.0 \pm 0.90 \mathrm{a}$ & $2.06 \pm 0.14 b$ & $21.0 \pm 1.56 \mathrm{~b}$ & $-31.7 \pm 0.25 b$ & $-2.01 \pm 0.90 \mathrm{~b}$ & $142.5 \pm 5.70 \mathrm{~d}$ \\
\hline
\end{tabular}

9 